\title{
Effect of Pre-treatment of Barley Grain on Germination and Seedling Growth Under Drought Stress
}

\author{
Mahmoud Abdel-Moneim Khafagy, Zain Al-Abidin Abdul Hamid Mohamed, Saad Farouk, \\ Hanan Khaleel Amrajaa
}

Faculty of Agriculture, Mansoura University, Mansoura, Egypt

Email address:

gadalla@mans.edu.eg (S. Farouk)

\section{To cite this article:}

Mahmoud Abdel-Moneim Khafagy, Zain Al-Abidin Abdul Hamid Mohamed, Saad Farouk, Hanan Khaleel Amrajaa. Effect of Pre-treatment of Barley Grain on Germination and Seedling Growth Under Drought Stress. Advances in Applied Sciences. Vol. 2, No. 3, 2017 , pp. 33-42. doi: $10.11648 /$ j.aas.20170203.12

Received: May 7, 2017; Accepted: May 25, 2017; Published: July 6, 2017

\begin{abstract}
Seed priming is currently a wide used commercial process that accelerates the germination rate and improves seedling uniformity in several crops. A laboratory study was conducted to evaluate the effect of grain priming treatments on barley grain germination and seedling growth under drought stress imposed by PEG-6000. The experiment was performed employing a factorial completely randomized block design with four levels of drought stress $(0,10,20$ and 30\% PEG6000) and 14 priming treatments (dry, hydropriming, 5, 10, 15\% PEG-6000; 500, 1000, $1500 \mathrm{mg} / \mathrm{K} \mathrm{KNO}_{3} ; 25,50,75 \mathrm{mg} / 1$ thiamin; 50, $100,150 \mathrm{mg} / \mathrm{l}$ sodium metasilicate) with five replications for each treatment. Germination percentage, germination index, energy of germination, mean germination time, seedling vigor, seedling length, 10 seedling fresh and dry weights were measured below the experimental conditions. Variance analysis results (ANOVA) showed extremely significant $(p<0.05$ ) variations between treatments in all traits. It had been discovered that increasing PEG concentrations up to $30 \%$ significantly decrease germination criteria and seedling growth traits and that priming treatments in most cases significantly increased all germination and seedling parameter. The most effective in this regard was $1000 \mathrm{mg} / \mathrm{l}$ potassium nitrate as compared with untreated control treatment. Priming treatments in most cases mitigates PEG effects as a major increase, particularly with 1000 $\mathrm{mg} / \mathrm{l}$ potassium nitrate. It is concluded that potassium nitrate at $1000 \mathrm{mg} / \mathrm{l}$ is helpful to enhance drought tolerance of barley grain germination and seedling growth.
\end{abstract}

Keywords: Barley, Drought, Grain Priming, Hydropriming, Osmopriming, Potassium Nitrate, Silicon, Thiamin

\section{Introduction}

Barley (Hordeum vulgare sbsp. Vulgare L.) belongs to family Poaceae (Graminae) is widely grown fourth most important world cereal following maize, wheat and rice. It is the main cereal in several dry areas of the Middle East and North Africa and is important for the livelihood of the many poor farmers. It is a very important supply of feed and forage for livestock, and of food for humans. Barley is comparable to different cereal grains in terms of caloric worth and protein content, however, contains higher levels of strong nutritional interest: tocols (vitamin E) and a water soluble fiber $\beta$ glucans $[1,2]$. There's strong proof that barley $\beta$-glucans will lower blood cholesterol levels, thereby reducing the danger of coronary heart and cancer diseases [3]. Besides grain, barley straw is additionally fed to animals for stall feeding, particularly throughout winter months once different feed resources are either scarce or in accessible.

Germination and seedling stablishment are critical stages within the plant life cycle, in special beneath a biotic stress condition like drought $[4,5]$. Under a biotic stress cereal production is wide restricted by poor stand establishment and germination tends to be irregular and might extend over long periods as well as inhibited seedling growth $[4,6]$. The ensuing poor crop stands leave gaps within the canopy, which are rapidly filling with vigorously growing weeds. These weeds vie with the crop plants for light, water and nutrients [7]. Observations in several semi-arid areas counsel that stand establishment, notably of cereals like as barley, is commonly very poor. Water stress not solely affects seed germination however additionally will increase the mean germination time in crop plants $[8,9]$. It's well established that speedy and uniform field emergence is two essential 
conditions to increase yield, quality and ultimately profits in crops.

There are several methods to beat the negative effects of drought stress. An excellent strategy is that the selection of cultivars and species for drought condition [10]. However another strategy for the chances to overcome drought stresses is by seed pre-treatments. One pragmatic approach to increment crop production is seed invigoration or seed priming [11]. Seed priming could be a low cost and low risk intervention wont to overcome poor stand establishment [12]. Seed priming could be a controlled hydration method followed by re-drying that permits the seeds to imbibe water and start internal biological processes necessary for germination, however that doesn't enable the seed to really germinate [13]. Seed priming is reportable as an efficient method for increasing seed vigor and improvement germination and seedling growth. A sturdy seedling establishment enhances aggressiveness against weeds, improves tolerance to environmental stresses and maximizes biological and grain yield $[14,15,16,17,18]$.

The helpful effects of seed priming technique have already been successfully expressed in several crop plants, i.e., wheat [19], andrice [20]. Seed priming improve germination uniformity and seedling establishment $[11,21]$, additionally to attenuate abiotic stresses throughout germination in barley [22]; wheat [23], and rice [24].

Common priming techniques include osmopriming, halopriming, hormonal priming, vitamin priming, hydropriming and others [16, 17, 25, 26]. Harrisetal. [27] introduced an occasional value, low risk technology referred to as 'on-farm seed priming' that will be acceptable for all farmers, no matter their socioeconomic standing. However, the manner the priming is finished could well influence the results. The principle is that sowing soaked seed decreases the time required for germination and should permit the seedling to escape deteriorating soil physical conditions. Besides higher establishment, farmers have reportable that primed crops grew a lot of vigorously, flowered earlier and yielded higher [16].

It was discovered that hydropriming much ensured speedy and uniform germination accompanied with low abnormal seedling percentage under control and/or drought conditions $[17,28,29,30]$. Application of potassium nitrate as a priming treatment resulted in higher seed germination and stand establishment [16, 17, 31]. Several investigators have reported that silicon enhanced the drought tolerance in wheat [32], maize [33] and sorghum [34]. Recently silicon (Si) priming is one amongst the most important strategies, which might improve a biotic stress tolerance [35].

Osmopriming was found to establish deep roots more rapidly than untreated seed, in this concern, El-Saidy et al. [16] and Farouk and El-Saidy [17] reportable that primed sunflower achens emerged 1-3 days earlier than non-treated ones, and early seedling gemergence junction rectifier to a variety of advantages later. Thiamin needs for growth and differentiation of some plant species are reportable [36, 37]. But there is a little information about its role in improving drought tolerance of plants. Though the results of priming treatments on germination of some seed crops has been studied, however very little information is available on the invigorating of barley grain under drought stress. With these facts in mind, the present study was undertaken to evaluate the effect of grain priming in order to achieve an effective solution for optimizing the plant seedling growth and establishment under drought stress.

\section{Subjects and Methods}

This experiment was carried out within the Agricultural Botany Department lab. , Fac. Of Agriculture, Mansoura University, Egypt throughout the period of 2015/2016 to study the ameliorating effect of priming treatments on grain germination and seedling growth of barely under drought stress (PEG-6000). The experiment design was factorial (4x14) organized in a completely randomized block design, with 5 replications and thiry grains per replicate. The main factor was PEG-induced drought stress at 10, 20 and 30\%, and the sub-factor represent priming agent in 14 sets (13 priming agent i.e., hydropriming, osmopriming with 5, 10, and $15 \%$ PEG-6000; vitamin priming with 25,50 , and 75 $\mathrm{mg} / \mathrm{l}$ thiamin; nutria-priming with 500, 1000 and $1500 \mathrm{mg} / \mathrm{l}$ potassium nitrate $\left(\mathrm{KNO}_{3}\right)$ as well as 50,100 and $150 \mathrm{mg} / \mathrm{l}$ sodium metasilicate $\left(\mathrm{Na}_{2} \mathrm{SiO}_{3}\right)$; plus non-primed (dry grains ) as control).

The grains of barley (Hordium vulgare L.) cv Giza129 used in the present investigations were secured from the Field Crop Res. Inst., ARC, Giza, Egypt. Before the experiment begin, grains were sterilized in $70 \%$ ethanol for 5 min, then rinsed with distilled water and surface dried by placing them between paper towels for $30 \mathrm{~min}$. at room temperature [38]. The sterilized grains were divided into 14 sets. The first set was non-primed (dry grain) to serve as control; the remaining set of grain was separately soaked for $24 \mathrm{~h}$ in distilled water or aqueous solutions of priming agents as mentioned above. The subsequent standard priming treatment was adopted altogether experiments; one layer of barley grains was submerged in every priming solution or distilled water, to a depth of one $\mathrm{cm}$ on top of the highest of the seeds for twenty-four hr at room temperature within the dark [26]. The ratio of seed weight to solution volume was $1: 5(\mathrm{~g} / \mathrm{ml})$ [11]. The treated grains were rinsed totally with tap water 3 times for about 2 minutes, and re-dried well with regards to their original weight in the shade [39]. Once drying, all the treated and non-treated grains were sealed in polyethylene bag until more use [39].

Every set was divided into four groups each one composed of 600 grains. The groups transferred to a sterile germination plate containing two layers of filter paper. The first group was wetness with twenty cubic centimeter of distilled water (control). The other three groups were wetness severally with $20 \mathrm{ml}$ of PEG solution concentration at 10;20 and 30\% that were prepared in $1 / 10$ strength Hogland solution for fulfillment of nutrient necessities. Thirty grains were placed on every germination plate. Germination plate was inspected 
daily and distilled water was added as required to compensate for evaporation loss. Grains are considered physiologically germinated when the radical reach approximately 2-3 $\mathrm{mm}$ long [40]. The germinated grains were counted and first count defined as the number of germinated grains at the $2^{\text {nd }}$ days from planting. Then, each twenty four hours the number of germinated grains was counted till the end of germination test (8days).The experiment was repeated two times and therefore the following data was recorded:

\subsection{Germination Parameters}

Germination percentage $(\mathrm{G} \%)$ was defined as the production of normal seedling [41] and therefore the initiation of germination was thought of to possess occurred whenever the emergent radical was visible. The daily record of germinated seed was taken up to eight days from setting up of the test. Data were counted daily and the sum of the data after fourteen days was calculated by using the following formula: $\mathrm{G} \%=$ (number of normal seedlings / Total number of grains) $x$ 100.The germination index(GI) has been calculated by the formula as represented within the Association of Official Seed Analysis [42]: GI = (Germination percentage in each treatment/ Germination percentage in control treatment). Mean germination time(MGT) has been calculated supported the subsequent equation of Alvardo and Bradford [43]: MGT $=\left(\sum D n / \sum n\right)$, where $n$ is the number of grains that germinated on the day (D); D is the number of days counted from the beginning of germination. Energy of germination (EG) had been determined from the percentage of germinating grain at the first count (2 days once planting) relative to the whole number of tested grains [44].

\subsection{Seedling Parameters}

Seedling length $(\mathrm{cm})$ was recorded at eight days after planting. Ten seedlings were carefully uprooted randomly out of all the seedlings. The uprooted seedlings were washed with tap water and excess water was soaked with tissue paper. Seedling length was measured with a ruler. Ten seedling fresh weight $(\mathrm{mg})$ : Ten seedling samples of the above samples were packed separately in paper bags and 10 seedling fresh weights were recorded by an electronic balance (Model: Satorious, a200S). Ten seedling dry weight (mg): After taking fresh weight those ten seedling sample packages were dried in an electric oven maintaining $72^{\circ} \mathrm{C}$ temperature for 48 hours. After drying, the seedling dry weights were weighed by an electronic balance (Model: Satorious, a200S) and they were recorded accordingly. Seedling vigor index (SVI): it was calculated according to the formula suggested by Vashisth and Nagarajan, [45], SVI $=($ Seedlings Length $x$ Germination Percentage $) / 100$.

\subsection{Statistical Analysis}

Data were analyzed by analysis of variance (ANOVA) technique using computer software MSTATC and significant treatment means were compared using least significance difference (LSD) test at 0.05 probability level according to Gomez and Gomez [46].

\section{Results and Discussion}

\subsection{Grain Germination Parameters}

Analysis of variance indicated that grain priming and drought stress had a significant effect on grain germination parameters of barley alone or incombinations (Tables1, 2). Data presented in tables $(1,2)$ revealed that increasing drought stress up to $30 \%$ PEG-6000 significantly decreased the germination parameters. The maximum reduction was obtained due to $30 \%$ PEG-6000 which decreased germination percentage "G\%", germination index "GI", mean germination time "MGT", the energy of germination "EG" and seedling vigor index "SVI". On the other hand, grain priming in various agents had significant effects on germination parameters of barley. Potassium nitrate at $1000 \mathrm{mg} / \mathrm{l}$ was the best given the highest G\%, GI, EG and SVI as compared with other priming agents or non-primed dry grain. As regards to mean germination time, application of $500 \mathrm{mg} / \mathrm{l}$ potassium nitrate gave the highest value compared with untreated control plant, meanwhile, grain osmopriming in $15 \%$ PEG gave the lowest mean germination time. Moreover, it is obvious from the present table (2) indicated that in most cases the application of grain priming with $15 \%$ PEG generally gave the lowest values of germination parameters.

Table 1. Effect of drought $(D)$, grain priming agent $(P)$ and their combinations on germination percentage and germination index of barley seedlings.

\begin{tabular}{|c|c|c|c|c|c|c|c|c|c|c|}
\hline \multirow{3}{*}{ Priming Agent(P) } & \multicolumn{5}{|c|}{ Germination Percentage } & \multicolumn{5}{|c|}{ Germination Index } \\
\hline & \multicolumn{5}{|c|}{ Drought (PEG\%,D) } & \multicolumn{5}{|c|}{ Drought (PEG\%,D) } \\
\hline & 0 & 10 & 20 & 30 & Mean & 0 & 10 & 20 & 30 & Mean \\
\hline Dry & 91.99 & 91.99 & 87.99 & 74.66 & 86.66 & 1.000 & 1.000 & 0.657 & 0.812 & 0.942 \\
\hline Hydropriming & 95.99 & 96.00 & 94.66 & 94.66 & 95.33 & 1.044 & 1.044 & 1.029 & 1.029 & 1.036 \\
\hline Potassium nitrateat $500 \mathrm{mg} / \mathrm{l}$ & 98.66 & 98.66 & 97.33 & 95.99 & 97.66 & 1.073 & 1.073 & 1.058 & 1.044 & 1.062 \\
\hline Potassium nitrateat $1000 \mathrm{mg} / 1$ & 98.66 & 100.0 & 98.66 & 95.99 & 98.33 & 1.073 & 1.087 & 1.073 & 1.044 & 1.069 \\
\hline Potassium nitrateat $1500 \mathrm{mg} / 1$ & 95.99 & 95.99 & 94.66 & 93.33 & 94.99 & 1.044 & 1.044 & 1.029 & 1.015 & 1.033 \\
\hline Thiaminat50mg/1 & 95.99 & 95.99 & 94.66 & 93.33 & 94.99 & 1.044 & 1.044 & 1.029 & 1.015 & 1.033 \\
\hline Thiaminat75mg/1 & 93.33 & 93.33 & 89.99 & 89.33 & 91.49 & 1.015 & 1.015 & 0.978 & 0.971 & 0.995 \\
\hline Polyethyleneglycolat5\% & 94.66 & 93.33 & 90.66 & 93.33 & 92.99 & 1.029 & 1.015 & 0.986 & 1.015 & 1.011 \\
\hline Polyethyleneglycolat $10 \%$ & 91.99 & 91.99 & 89.32 & 79.99 & 88.33 & 1.000 & 1.000 & 0.971 & 0.870 & 0.960 \\
\hline
\end{tabular}




\begin{tabular}{|c|c|c|c|c|c|c|c|c|c|c|}
\hline \multirow{3}{*}{ Priming Agent(P) } & \multicolumn{5}{|c|}{ Germination Percentage } & \multicolumn{5}{|c|}{ Germination Index } \\
\hline & \multicolumn{5}{|c|}{ Drought (PEG\%,D) } & \multicolumn{5}{|c|}{ Drought (PEG\%,D) } \\
\hline & $\mathbf{0}$ & 10 & 20 & 30 & Mean & $\mathbf{0}$ & 10 & 20 & 30 & Mean \\
\hline Polyethyleneglycolat $15 \%$ & 90.66 & 90.66 & 83.99 & 58.66 & 80.99 & 0.986 & 0.986 & 0.913 & 0.638 & 0.881 \\
\hline Sodium metasilicateat50mg/1 & 94.66 & 94.66 & 93.33 & 91.99 & 93.66 & 1.029 & 1.029 & 1.015 & 1.000 & 1.015 \\
\hline Sodium metasilicateat $100 \mathrm{mg} / 1$ & 97.33 & 97.33 & 95.99 & 94.66 & 96.33 & 1.058 & 1.058 & 1.050 & 1.029 & 1.049 \\
\hline Sodium metasilicateat $150 \mathrm{mg} / 1$ & 98.66 & 97.33 & 95.99 & 95.99 & 96.99 & 1.073 & 1.058 & 1.044 & 1.044 & 1.055 \\
\hline Mean & 95.33 & 95.14 & 92.90 & 88.85 & $===$ & 1.036 & 1.034 & 1.010 & 0.966 & $===$ \\
\hline LSD0.05 & $\mathrm{D} 2.123$ & P3.971 & & 943 & & D0.023 & P0. & & 0861 & \\
\hline
\end{tabular}

Table2. Effect of drought (D), grain priming agent $(P)$ and their combinations on germination energy, mean germination time and seedling vigor index of barley seedlings.

\begin{tabular}{|c|c|c|c|c|c|c|c|c|c|c|}
\hline \multirow{3}{*}{ Priming Agent(P) } & \multicolumn{5}{|c|}{ Germination Energy } & \multicolumn{5}{|c|}{ Mean Germination Time } \\
\hline & \multicolumn{5}{|c|}{ Drought (PEG\%) } & \multicolumn{5}{|c|}{ Drought (PEG\%) } \\
\hline & $\mathbf{0}$ & 10 & 20 & 30 & Mean & $\mathbf{0}$ & 10 & 20 & 30 & Mean \\
\hline Dry & 92.00 & 90.66 & 88.00 & 53.33 & 81.00 & 3.160 & 2.760 & 2.640 & 2.240 & 2.700 \\
\hline Hydropriming & 92.00 & 93.33 & 94.66 & 94.66 & 93.66 & 2.880 & 2.880 & 2.840 & 2.840 & 2.860 \\
\hline Potassium nitrateat500mg/1 & 93.33 & 96.00 & 95.99 & 94.66 & 94.99 & 2.960 & 2.960 & 2.920 & 2.880 & 2.930 \\
\hline Potassium nitrateat $1000 \mathrm{mg} / 1$ & 98.66 & 98.66 & 95.99 & 94.66 & 96.99 & 2.960 & 2.840 & 2.960 & 2.880 & 2.910 \\
\hline Potassium nitrateat $1500 \mathrm{mg} / 1$ & 95.99 & 96.00 & 91.99 & 93.33 & 94.33 & 2.880 & 2.880 & 2.840 & 2.800 & 2.850 \\
\hline Thiaminat50mg/1 & 95.99 & 95.99 & 92.00 & 92.00 & 93.99 & 2.880 & 2.880 & 2.840 & 2.800 & 2.850 \\
\hline Thiaminat75mg/l & 91.99 & 93.33 & 90.66 & 87.99 & 90.99 & 2.800 & 2.800 & 2.760 & 2.680 & 2.760 \\
\hline Polyethyleneglycolat5\% & 94.66 & 90.66 & 88.00 & 92.00 & 91.33 & 2.840 & 2.800 & 2.720 & 2.800 & 2.790 \\
\hline Polyethyleneglycolat $10 \%$ & 89.33 & 87.33 & 89.33 & 78.66 & 86.16 & 2.760 & 2.760 & 2.680 & 2.440 & 2.660 \\
\hline Polyethyleneglycolat $15 \%$ & 86.66 & 90.66 & 82.66 & 48.00 & 77.00 & 2.720 & 2.720 & 2.520 & 1.760 & 2.430 \\
\hline Sodium metasilicateat50mg/1 & 91.99 & 94.66 & 97.33 & 92.00 & 94.00 & 2.840 & 2.840 & 3.120 & 2.760 & 2.890 \\
\hline Sodium metasilicateat $100 \mathrm{mg} / 1$ & 97.33 & 97.33 & 96.00 & 94.66 & 96.33 & 2.920 & 2.920 & 2.880 & 2.840 & 2.890 \\
\hline Mean & 93.52 & 94.04 & 91.61 & 85.33 & & 2.889 & 2.843 & 2.809 & 2.654 & $===$ \\
\hline LSD0.05 & D2.769 & P5.182 & DP1.364 & & & D0.077 & $\mathrm{P} 0.145$ & DP0.291 & & \\
\hline
\end{tabular}

Table 2. Continue.

\begin{tabular}{|c|c|c|c|c|c|}
\hline \multirow{3}{*}{ PrimingAgent(P) } & \multicolumn{5}{|c|}{ SeedlingVigorIndex } \\
\hline & \multicolumn{5}{|c|}{ Drought (PEG\%) } \\
\hline & 0 & 10 & 20 & 30 & Mean \\
\hline Dry & 13.898 & 12.884 & 9.156 & 4.002 & 9.985 \\
\hline Hydropriming & 19.202 & 15.940 & 13.364 & 9.622 & 14.532 \\
\hline Potassium nitrateat $500 \mathrm{mg} / \mathrm{l}$ & 21.170 & 18.666 & 15.652 & 11.802 & 16.823 \\
\hline Potassium nitrateat $1000 \mathrm{mg} / 1$ & 21.974 & 20.140 & 16.390 & 12.750 & 17.814 \\
\hline Potassium nitrateat $1500 \mathrm{mg} / 1$ & 18.854 & 15.786 & 12.626 & 9.084 & 14.088 \\
\hline Thiaminat50mg/1 & $18 . .58$ & 15.944 & 13.672 & 8.830 & 14.351 \\
\hline Thiaminat75mg/1 & 15.310 & 13.858 & 10.216 & 6.696 & 11.520 \\
\hline Polyethyleneglycolat5\% & 16.942 & 14.216 & 10.994 & 7.424 & 12.394 \\
\hline Polyethyleneglycolat $10 \%$ & 14.594 & 13.204 & 10.592 & 5.548 & 10.985 \\
\hline Polyethyleneglycolat $15 \%$ & 13.500 & 12.808 & 8.688 & 3.514 & 9.628 \\
\hline Sodium metasilicateat50mg/1 & 16.980 & 14.206 & 11.416 & 7.618 & 12.555 \\
\hline Sodium metasilicateat $100 \mathrm{mg} / 1$ & 20.234 & 17.546 & 14.516 & 10.224 & 15.630 \\
\hline Mean & 17.822 & 15.546 & 12.484 & 8.328 & \\
\hline LSD0.05 & D0.6426 & $\mathrm{P} 1.2026$ & DPNS & & \\
\hline
\end{tabular}

Regarding to the interaction between drought stress and grain priming agents, the data in Tables $(1,2)$ indicate that in most cases all interactions significantly increased grain germination percentage and germination index except the grain priming with $75 \mathrm{mg} / \mathrm{l}$ thiamin and $10 \%$ PEG under moderate or severe drought stress potential; with 5\% PEG under moderate drought stress, as well as PEG at $15 \%$ under all drought potential stress. The highest germination percentage was obtained due to grain priming in $1000 \mathrm{mg} / \mathrm{l}$ potassium nitrate under low drought stress potential as compared with control or normal conditions.
The data in the same tables proved that speed germination index markedly increased in most cases by grain priming in all agent under all drought stress as compared with untreated control plants, except $75 \mathrm{mg} / 1$ thiamin and 10\% PEG under moderate and severe water stress; and 5\% PEG under moderate water stress as well as $15 \%$ PEG under all water stress. Grain priming in $1000 \mathrm{mg} / 1$ potassium nitrate gave the highest value of germination index compared with other priming treatments or untreated control. Also, application of priming agent counteracts the harmful effect of drought stress as compared with un-priming plants under such drought 
potential.

Regarding mean germination time, the data in the same table indicate that, grain priming in 50 and $75 \mathrm{mg} / 1$ thiamin, 5 , $10,15 \% \mathrm{PEG}$, and $50 \mathrm{mg} / \mathrm{l} \mathrm{Si}$ significantly decreased mean germination time. The lower MGT was obtained due to $15 \%$ PEG under severe water stress. Moreover, potassium nitrate at $1000 \mathrm{mg} / \mathrm{l}$ and $100 \mathrm{mg} / \mathrm{l}$ silicon significantly increased the germination energy under control or drought stress. Also hydropriming, $500 \mathrm{mg} / 1$ potassium nitrate, $150 \mathrm{mg} / \mathrm{l} \mathrm{Si}$ under water stress gave a significant increase as compared with untreated control plants. Meanwhile potassium nitrate at $1500 \mathrm{mg} / \mathrm{l}$, and thiamin at 25 and $50 \mathrm{mg} / \mathrm{l}$ gave a significant increase under control or low water stress. The greatest germination energy was obtained due to $1000 \mathrm{mg} / \mathrm{l}$ potassium nitrate as compared with untreated control plant.

All priming treatment markedly increased seedling vigor index and counteracted the harmful effects of drought as compared with untreated treatment under drought stress. The highest SVI was obtained due to application of $1000 \mathrm{mg} / \mathrm{l}$ potassium nitrate under control treatment.

Germination and establishment are critical phases within the life time of aplant when they are the foremost liable to injury, disease, and water stress [47]. Germination is one amongst the foremost drought-sensitive plant growth stages and severely inhibited with increasing drought stress potential. Drought stress during the initial stage of crop hampered germination characteristics, resulted in delaying and erratic seedling emergence and stand establishment in many crops. In the present investigation, increasing drought stress induced a significant and prominent reduction in barley germination criteria. Similar results were reported $[4,6,29$, $32]$, on a range of plant species. It can be proposed that under water restriction the velocity of water absorption is affected, where the absorption and consequently the hydrolysis and mobilization of carbohydrates are slower [48]. Drought also disturbs the plant growth owing to loss of turgor, as water supply from the xylem to the surrounding elon gating cells is interrupted [49]. The reduction in germination percentage under drought stress could be as a result of declining within the cellular enlargement and reduced water potential, and causing a complete inhibition of seed germination [50].The first physiological disorder, which takes place during germination, is the reduction in imbibitions of water by seeds which leads to a series of metabolic changes, including a general reduction in hydrolysis and utilization of the seed reserve [51].

Priming treatment is a successful practice for improving seed germination criteria performance and/or counteracted the harmful effect of drought stress. These results corroborate with the finding of Jalilian et al. [52]; Rouhi et al. [53] for hydropriming; and Ansari et al. [4]; Rouhi et al. [6]; Espanany et al. [54] for potassium nitrate priming; and Afef et al. [32], Hameed et al. [35]; Ghajari et al. [55] for silicon priming as well as Rouhi et al. [53]; Aghbolaghi and Sedghi [56] for polyethyleneglycol, and Hamada and Khulaef [57]; Sayed and Gadalla [58] for thiamin they found that germination parameter were significantly increased by seed priming treatment under normal or drought stress conditions. Moreover, primed seedlings are known to emerge additional quickly and grow additional vigorously than those from nonprimed seeds [59].

One of the positive and effective reasons of priming treatment on the seed germination probably due to hormonal imbalance and reduced the proportion of growth inhibiting substances such as abscisic acid [60]. In this concern Hopkins [61] found that priming strategies cause ABA hydrolysis and increasing the phenolic compounds leaching to the aqueous solution, which might act as germination inhibitors. The positive effect of priming technology was most likely as a result of the stimulatory effects of priming on the early stage of germination processes by the mediation of cell division in germinating seeds. Furthermore, the literature indicates beneficial effects of priming related to repair and build-up of nucleic acids, inducing protein synthesis and repair of membranes [62]. Finally, priming treatment enhances the activity of antioxidant enzymes in treated plants which helping in alleviated the oxidative stress induced by drought on seed germination criteria [63].

Recently, numerous hypotheses have been proposed to account for the action of nitrate in seed germination, including, action of the Pentose Phosphate Pathway [64], stimulation of oxygen uptake [65] and action as a co-factor of phytochrome [66]. The greater efficiency of potassium nitrate priming is probably associated with the osmotic advantage that $\mathrm{K}^{+}$have in improving cell water standing, and additionally in this they act as cofactors within the activities of various enzymes, most of which are active once reserve mobilization and radical protrusion are in progress [49]. Moreover Khan et al. [67] revealed that the presence of nitrate during imbibitions could offer a further substrate for amino acid and protein synthesis for the enhancement of germination throughout priming and time to emergence of seedlings.

There is terribly rare data concerning the influences of thiamin priming treatment on seed germination and seedling growth and vigor and need more and more experiments. In accordance with the results of the current investigation, seed dressing with thiamin increased germination rate of bean seedlings [37]. Thiamin molecules, consisting of a pyrimidine and a thiazole moiety are an incipient thiol. Thiol compounds like glutathione have vital functions as constituents of free radical scavenging systems. Impairment of those defense mechanisms throughout prolonged periods of oxygen deprivation is taken into account as a serious cause for post-anoxic injuries of plant tissues under stress conditions. It has been reported from the current study and by alternative investigators that osmopriming may be a less effective technique than hydropriming for improving seed germination and MGT $[16,17]$.This dangerous impact could be as a result of the high concentration of PEG has some disadvantages like the reduction of oxygen concentration within the solution due to the viscous nature of PEG successively could have negative effects on each protein synthesis and degradation and hamper respiration 
processes throughout seed germination. Also, the dangerous impact of high PEG solution could also be as a result of its effect in reducing seed water imbibitions as compared with distilled water [68] as a result of its osmoticeffect.

\subsection{Seedling Growth}

Data presented in Table 3 indicate the effects of drought levels, priming agents and their combinations on barley seedling growth. Analysis of variance indicates significant difference due to the effect of various levels of drought stress in respect ofs eedling growth parameters. The longest seedling length, high fresh and dry weights were found from the control treatment which was statistically different from other treatments. Likewise, Increasing drought level upto $30 \%$ PEG decreased seedling length, fresh and dry weights of seedling, particularly under high drought level "30\%". Grain priming increased markedly seedling length, seedling fresh and dry weight. Among the seed priming treatments, the highest values of seedling length, seedling fresh weight, seedling dry weight were obtained as a result of grain priming in $1000 \mathrm{mg} / \mathrm{l}$ potassium nitrate as compared with control treatment. Additionally the data within the same table revealed that $15 \%$ PEG gave the lowest values followed by hydro-priming techniques. Correspondingly, non-priming noted the shortest shoot.

Table3. Effect of drought (D), grain priming agent $(P)$ and their combinations on seedling length and 10 seedling fresh and dry weights of barley seedlings.

\begin{tabular}{|c|c|c|c|c|c|c|c|c|c|c|c|c|c|c|c|}
\hline \multirow{3}{*}{ Priming Agent(P) } & \multicolumn{5}{|c|}{ Seedling Length(cm) } & \multicolumn{5}{|c|}{10 Seedling Fresh Weight (mg) } & \multicolumn{5}{|c|}{10 Seedling Dry Weight (mg) } \\
\hline & \multicolumn{5}{|c|}{ Drought (PEG \%, D) } & \multicolumn{5}{|c|}{ Drought (PEG\%,D) } & \multicolumn{5}{|c|}{ Drought $($ PEG\%,D) } \\
\hline & 0 & 10 & 20 & 30 & Mean & 0 & 10 & 20 & 30 & Mean & $\mathbf{0}$ & 10 & 20 & 30 & Mean \\
\hline Hydropriming & 20.0 & 16.6 & 14.1 & 10.1 & 15.2 & 3270 & 3174 & 2728 & 1438 & 2653 & 416 & 382 & 330 & 305 & 358 \\
\hline Potassium nitrateat500mg/1 & 21.5 & 18.9 & 16.0 & 12.3 & 17.2 & 3707 & 3347 & 2900 & 1806 & 2940 & 463 & 411 & 348 & 314 & 384 \\
\hline Potassium nitrateat $1000 \mathrm{mg} / 1$ & 22.3 & 20.1 & 16.6 & 13.2 & 18.0 & 3747 & 3440 & 2901 & 1821 & 2977 & 487 & 424 & 354 & 327 & 398 \\
\hline Thiaminat25mg/1 & 18.1 & 15.8 & 13.2 & 9.64 & 14.2 & 2804 & 2894 & 2427 & 1351 & 2369 & 392 & 373 & 311 & 280 & 339 \\
\hline Thiaminat50mg/1 & 19.7 & 16.6 & 14.4 & 9.66 & 15.1 & 3159 & 3079 & 2541 & 1427 & 2551 & 408 & 375 & 324 & 295 & 350 \\
\hline Thiaminat75mg/1 & 16.4 & 14.9 & 11.3 & 7.56 & 12.5 & 2633 & 2458 & 1933 & 1215 & 2059 & 354 & 345 & 267 & 258 & 306 \\
\hline Polyethyleneglycolat5\% & 17.8 & 15.2 & 12.1 & 7.92 & 13.2 & 2712 & 2515 & 2003 & 1236 & 2116 & 363 & 357 & 280 & 267 & 316 \\
\hline Polyethyleneglycolat $10 \%$ & 15.7 & 14.3 & 11.8 & 6.92 & 12.2 & 2493 & 2427 & 1900 & 1127 & 1987 & 345 & 341 & 258 & 253 & 299 \\
\hline Polyethyleneglycolat15\% & 14.8 & 14.0 & 10.3 & 6.10 & 11.3 & 2274 & 2092 & 1467 & 1084 & 1729 & 308 & 307 & 235 & 208 & 264 \\
\hline Sodium metasilicateat $100 \mathrm{mg} / 1$ & 20.7 & 17.9 & 15.0 & 10.7 & 16.1 & 3557 & 3226 & 2854 & 1656 & 2823 & 424 & 392 & 335 & 311 & 365 \\
\hline Sodium metasilicateat $150 \mathrm{mg} / 1$ & 20.7 & 17.9 & 15.7 & 11.0 & 16.3 & 3670 & 3334 & 2854 & 1792 & 2912 & 433 & 405 & 341 & 315 & 373 \\
\hline Mean & 18.6 & 16.2 & 13.3 & 9.20 & $===$ & 3003 & 2847 & 2360 & 1415 & $===$ & 397 & 368 & 303 & 279 & $===$ \\
\hline I SD0 05 & $\mathrm{D}$ & $\mathrm{P}$ & DP & & & $\mathrm{D}$ & $\mathrm{P}$ & DP19 & & & D & $\mathrm{P}$ & $\mathrm{D}$ & & \\
\hline LSDU.05 & 0.620 & 1.160 & NS & & & 51.35 & 96.07 & 2.15 & & & 4.870 & 9.112 & P1822 & & \\
\hline
\end{tabular}

As regards to interactions between priming treatments, moderate and high drought levels, data in Table 3 show that priming agent partially counteracted the harmful effects of drought especially at severe drought stress potential.

The negative effects of drought on the growth of early seedling were much more than on the germination of barley grains. The present results showed that, drought stress brought by PEG-6000 inhibited seedling growth parameters and seedling vigor index. The findings are in accordance with other researchers $[53,69]$.The observed reduction in seedling growth under drought stress could also be as a result of cell expansion suppression and cell growth that's in response to low turgor pressure [70] and will be attributed to the repressive impact of $\mathrm{ABA}$ that was induced by drought on cell division and/or cell enlargement [71]. Also, the inhibition effects of drought stress on growth parameters of plants might be due to inhibits the growth through reduced water absorption, changes in water relations of tissues exposed to low water potential, accumulation of ions in tissues and stomata conductance of leaves [72]. Moreover, Soltani et al. [8] found that wheat seedling dry weight reduction in response to environmental stresses may be a consequence of the decrease in mobilized seed reserve as a result of low water uptake by the germinating seeds.

The experimental results showed that grain priming showed significant response in terms of seedling length, seedling fresh and dry weight as well as seedling vigor index. These findings are in accordance with the results reported by Jalilian et al [52] in barley, Golizadeh et al. [73] in Cannabis seed; and Kalpana et al [74] in wheat. Faster emergence rate after priming may be due to increased rate of cell division in the root tips of seedlings from primed seeds as reported in wheat [28] and sunflower [29].

Potassium application increased drought tolerance in plants by regulation a spread of processes, like osmoregulation, charge balance, energy status, and proteins ynthesis [75]. Many studies, typically underneath short durations of drought stress, have provided proof of the role of $\mathrm{K}$ in mitigating drought stress by enhancement of NRA and accumulation of $\mathrm{K}^{+}$and glycinebetaine [75, 76]. It is well known that application of silicon inducing growth and development of plants under drought stress $[34,77]$. The present investigation revealed that grain priming with sodium silicate improved the seedlings growth under drought. Similarly, Afef et al., [32] has 
additionally been indicated the improved emergence and better seedling stand establishment afters eed priming. Also, Si decreased significantly the level of jasmonic acid and ABA, which play a key role in regulation physiological processes related to plant resistance to biotic and a biotic stresses, thereby protective the plant metabolism from ROS [78]. Kim et al. [79] ascribed the Si-mediated reduction within the levels of those plant hormones in rice plants exposed to environmental stress to the ameliorative effect of silicon on the stress intensity by regulation the expression of genes responsible for the synthesis of $\mathrm{ABA}$ and $\mathrm{JA}$.

Generally, it was found that the applied vitamins like thiamin could stimulate the growth of seedlings. In accordance with this, El-Zawahry and Hamada [80] recorded that, soaking of Solanum melanogena seeds, in thiamin increased shoot and root fresh and dry weights compared with those of the control. It is known that thiamin, as a functional coenzyme thiamin pyrophosphate, plays an integral role within the regulation of the carbon metabolism in plants. Bender [81] mentioned that pyridoxine having the pyridine ring represents a precursor for the essential enzyme pyridoxal-phosphate, which is utilized in all phases of amino acid metabolism.

The useful effects of hydropriming are attributed to the mobilization in embryonic tissues of enzyme activities needed for fast seed germination and of compounds like free amino acids, proteins, and soluble sugars from storage organs [21]. The improved seedling fresh and dry weight of barley could also be attributed to optimum availability of nutrients to seedling soon after their emergence, which enhanced the early grow thand thus resulted in improved barley fresh and dry weight within the nutrient primed seed treatments. These results are in accordance with the findings of Yari et al. [82], who observed maximum seedling growth rate for each wheat cultivars in seeds treated with distilled water. These findings are in agreement with previous reports [68]. Many researchers reported the positive impact of hydropriming on seedling emergence rate, seedling establishment, and early vigor.

Generally, It's over that $1000 \mathrm{mg} / \mathrm{l}$ potassium nitrate is beneficial to boost barley grain germination and seedling growth under control or drought conditions.

\section{References}

[1] P. Åman and H. Graham. "Analysis of total and insoluble mixed-linked (1-3), (1-4)-ß3-D-glucans in barley and oats". Journal of Agriculture and Food Chemistry vol. 35, pp. 704709, 1987.

[2] M. Oscarsson, R. Andersson, A. C. Salomonsson and P. Åman, "Chemical composition of barley samples focusing on dietary fiber components. J. Cereal Sci vol. 24, no. 2, pp. 161-170, 1996.

[3] V. M. Martinez, R. K. Newman and C. W. Newman, "Barley diets with different fat sources have hypocholesterolemic effects in chicks. J. Nut. Vol 122, no. 5, pp 1070-1076, 1992.

[4] O. Ansari, H. R. Choghazardi, F. Sharif Zadeh, and H. Nazarli. "Seed reserve utilization and seedling growth of treated seeds of mountain ray (Seecale montanum) as affected by drought stress". Cercetari Agronomicein Moldova vol. 2, no. 150, pp. 43-48, 2012.

[5] M. H. Jorenush and R. Mohsen, Effect of drought and salinity tensions on germination and seedling Growth of Artichoke (Cynara Scolymus L.). Int. J. Adv. Biol. Biom. Res, vol. 3, no. 3, pp. 297-302, 2015.

[6] H. R. Rouh, M. A. Aboutalebian, and F. Sharif-Zadeh, "Seed priming improves the germination traits of tall fescue (Festuca arundinacea)". Not Sci Biol vol 3, no. 2, pp. 57-63, 2011.

[7] M. J. Kropff and H. H. Vanlaar, "Modeling crop-weed interactions". CAB international Wallingford, U.K., 272, 1993.

[8] A. Soltani, M. Gholipoor and E. Zeinali, "Seed reserve utilization and seedling growth of wheat as affected by drought and salinity", Environ. Exp. Bot., vol. 55, pp. 195-200, 2006.

[9] F. Mokhberdoran, S. M. Nabavi Kalat, R. Sadrabadi Haghighi, "Effect of temperature, iso-osmotic concentration of $\mathrm{NaCl}$ and PEG agents on germination and some seedling growth yield components in rice (Oryza sativa L.)". Asian J. Plant Sci., vol. 8, pp. 409-416, 2009.

[10] M. Ashraf, H. Bokhari and S. N. Cristiti. "Variation in osmotic adjustment of lentil (Lens culinaris Medik) in response to drought". Acta Bot Neerl. Vol. 41, pp. 51-62, 1992.

[11] M. Farooq, S. M. A. Basra, R. Tabassum and N. Ahmad. "Evaluation of seed vigour enhancement techniques on physiological and biochemical techniques on physiological basis in coarse rice (Oriza sativa L.)". Seed Sci Technol vol. 34, pp. 741-750, 2006.

[12] D. Harris, "The effects of manure, variety, seedlings, seed priming, depth and date of sowing on the emergence and early growth of Sorghum bicolor (L.) Moench in semi arid Botswana. Soil and Tillage Research, vol. 40, pp. 73-88, 1996.

[13] P. Halmer, "Methods to improve seed performance". In R. L. Benech-Arnold and R. A. Sanchez (Eds) Seed Physiology, Applications to Agriculture. Food Product Press, New York, 2003.

[14] M. Arif, M. T. Jan, B. K. Marwat and A. M. Khan. "Seed priming improves emergence and yield of soybean". Pak J Bot. vol. 40, pp. 1169-1177, 2008.

[15] A. Hosseein, Farahani and M. Karsa, "Effect of hydro-priming on seedling vigour in Basil (Ocimum basilicum L.) under salinity conditions". Advances in environmental biology, vol. 5 , no. 5 , pp. 828-833.

[16] Aml E. A. EL-Saidy, S. Farouk, and H. M. Abd EL-Ghany, "Evaluation of different seed priming on seedling growth, yield and quality components in two sunflower (Helianthus annus L.) cultivars". Trends in Applied Sciences Research vol. 6, no. 9, pp. 977-991, 2011. DOI: 10.3923/tasr.2011.977.99.

[17] S. Farouk and Aml E. A. EL-Saidy, "Seed Invigoration Techniques To Improve Germination and Early Growth of Sunflower Cultivars". Journal of Renewable Agriculture vol. 1, no. 3, pp. 33-38, 2013. DOI. 10.12966/jra.06.02.2013.

[18] S. Hussain, M. Zheng, F. Khan, A. Khaliq, S. Fahad, and S. Peng, "Benefits of rice seed priming are off set permanently by prolonged storage and the storage conditions". Sci. Rep. vol. 5, pp. 8101, 2015. doi: 10.1038/srep08101 I. 
[19] M. Iqbal, and M. Ashraf, M., "Seed preconditioning modulates growth, ionic relations, and photosynthetic capacity in adult plants of hexaploid wheat under salt stress". J. Plant Nutr., vol. 30, pp. 381-396, 2007.

[20] N. Habib, M. Ashraf and M. S. A. Ahmad, "Enhancement in seed germinability of rice (Oryza sativa L.) by pre-sowing seed treatment with nitric oxide (NO) under salt stress". Pak. J. Bot. vol. 42, pp. 4071-4078, 2010.

[21] M. Ashraf and M. R. Foolad. "Pre-sowing seed treatment-a shotgun approach to improve germination growth and crop yield under saline and none-saline conditions". Advan. Agron, vol. 88, pp. 223-271, 2005.

[22] B. Abdulrahmani, K. Ghassemi-Golezani, M. Valizadeh and V. Feizi-As "Seed priming and seedling establishment of barley (Hordeum vulgare L.)". J Food Agric Environ vol. 5, pp. 179-184, 2007.

[23] H. Akbarimoghaddam, H. M. Galavi, A. Ghanbari and N. Panjehkeh. "Salinity effects on seed germination and seedling growth of bread wheat cultivars". Trakia J Sci vol. 9, pp.43-50, 2011.

[24] H. C. Kaymak, I. Guvene, F. Yarali and M. F. Donmez, The effects of bio-priming with PGPR on germination of radish (Raphanus sativus L.) seeds under saline conditions. Turk. J. Agric. For vol. 33, pp. 173-179, 2009.

[25] V. K. Patade, S. Bhargava and P. Suprasanna, "Halopriming impacts tolerance to salt and PEG induced drought stress in sugarcane". Agri Ecosys Environ vol. 134, no. 1-2, pp. 24-28. 2009.

[26] A. Wahid, A. Noreen, S. M. A. Basra, S. Gelani and M. Farooq, "Priming-induced metabolic changes in sunflower (Helianthus annuus) achenes improve germination and seedling growth". Botanical Studies vol. 49, pp. 343-350, 2008.

[27] D. Harris, A. Joshi, P. A. Khan, P. Gothkar and P. S. Sodhi,"On-far $\mathrm{m}$ seed priming in semi-arid agriculture: Development and evaluation in maize, rice and chickpea in India using participatory methods". Experimental Agriculture vol. 35 , pp. $15-29,1990$

[28] S. M. A. Basra, M. Farooq, I. Afzal and M. Hussain. "Influence of osmopriming on the germination and early seedling growth of coarse and fine rice". Int J Agr Biol vol. 8, pp. 19-21, 2006.

[29] M. D. Kaya, G. Okcu., M Atak, Y. C1k1l1 and O. Kolsarıc, "Seed treatments to overcome salt and drought stress during germination in sunflower (Helianthus annuus L.)", Eur. J. Agron., vol. 24, pp. 291- 295, 2006.

[30] I. Rajpar, Y. M. Khanif and A. A. Memon, "Effect of seed priming on growth and yield of wheat (Triticum aestivum L.) under non-saline conditions". Int. J. Agric. Res., vol. 1, no. 2. 2006.

[31] T. S. Lara, J. M. S. Lira, A. C. Rodrigues, M. Rakocevic and A. A. Alvarenga, Potassium nitrate priming affects the activity of nitrate reductase and antioxidant enzymes in tomato germination. J Agri Sci. vol. 6, pp. 72-80, 2014.

[32] O. Afef, A. Sourour, C. Zoubeir, R. Mounir, S.-A. Hajer and B. Y. Mongi. "Silicon alleviates adverse effect of drought stress induced by polyethylene glycol (PEG 8000) on seed germination and seedling growth of durum wheat varieties".
IOSR Journal of Electronics and Communication Engineering (IOSR-JECE) vol. 11, no. 6, pp 3-36, 2016.

[33] Y. Yong, S. Tai and X. Bao, "Effects of silicon on photosynthesis and antioxidative enzymes of maize under drought stress". Plant Science, vol. 18, pp. 531-536, 2007.

[34] T. Hattori, S. Inanaga, A. Hideki, A. Ping, M. Shigenori, L. Miroslava and A. Lux, "Application of silicon enhanced drought tolerance in Sorghum bicolor". Plant Physiology vol. 123, pp. 459-466, 2005.

[35] A. Hameed, A. S. Munir, A. Jamil and A. B. S. Maqsood, "Seed priming with sodium silicate enhances seed germination and seedling growth in wheat (Triticum aestivum L.) under water deficit stress induced by polyethylene glycol". Pak. j. life soc. Sci. vol. 11, no. 1, pp. 19-24, 2013.

[36] W. M. Proebsting, S. P. Maggard and W. W. Guo, "The relationship of thiamine to the Alt locus of Pisum sativum L". J. Plant Physiol., vol. 136, pp. 231-235, 1990.

[37] G. Neumann, H. A. Azaizeh and H. Marschner, "Thiamine (vitamin B1) seed treatment enhances germination and seedling growth of bean (Phaseolus vulgaris L.) exposed to soaking injury". Z. Pflanzen. Bodenk. Vol. 159, pp. 491-498, 1996.

[38] ISTA, International rules for seed testing. Seed Sci. and Technol. Vol. 13, pp. 299-320, 1985.

[39] S. M. A. Basra, M. N. Zia, T. Mahmood, I. Afzal and A. Khaliq. "Comparasion of different invigoration techniques in wheat (Triticum aestivum L.) seeds". Pak J Arid Agric vol. 5, pp. 11-16, 2002.

[40] ISTA, "Rules for Seed Testing". International Seed Testing Association. Seed Sci Technol, Zurich, Switzerland, 1996.

[41] ISTA (International Seed Testing Association), "International rules for seed testing". International Seed Testing Association, Bassersdorf, Switzerland, 2006.

[42] Association of Official Seed Analysts (AOSA) "Rules for testing seeds". J. Seed Technol. vol. 12, pp. 1-112, 1990.

[43] A. D. Alvardo, K. J. Bradford, and J. D. Hewitt. "Osmotic priming of tomato seeds. Effects on germination, field emergence, seedling growth and fruit yield". J. Amer. Soc. Hort. Sci. vol. 112, pp. 427-432, 1987.

[44] S. Ruan, Q. Xue and K. Tylkowska, "The influence of priming on germination of rice (Oryza sativa L.) seeds and seedling emergence and performance in flooded soil". Seed Science and Technology, vol. 30, pp. 61-67, 2002.

[45] A. Vashisth and S. Nagarajan, Effect on germination and early growth characteristics in sunflower (Helianthus annuus) seeds exposed to static magnetic field. J. Plant Physiol. Vol. 167, no. 2, pp. 149-156, 2010.

[46] K. A. Gomez and A. A. Gomez, "Statistical procedures for agricultural research". Wiley, New York, USA, 1984.

[47] P. H. Raven, F. E. Ray, and E. E. Susan, "Biology of Plants", 7th Edition. New York: W. H. Freeman and Company Publishers. pp. 504-508, 2005.

[48] A. K. S. Lobato, C. F. Oliveira Neto, R. C. L. Costa, B. G. Santos Filho, F. K. S. Silva, F. J. R. Cruz, A. C. S. Abboud and H. D. Laughinghouse, Germination of sorghum under the influences of water restriction and temperature. Agric. J. vol. 3, no. 3, pp. 220-224, 2008. 
[49] L. Taiz and E. Zeiger, "Plant Physiology", $5^{\text {th }}$ edn. Sinauer Associates Inc Publishers, Sunderland, MA, USA, 2010.

[50] G. L. Dodd, and L. A. Donovan, "Water potential and ionic effects on germination and seedling growth of two cold desert shrubs". Am. J. Bot. vol. 86, pp. 1146-1153, 1999.

[51] J. Ahmad and M. Bano. "The effect of sodium chloride on the physiology of cotyledons and mobilization of reserve food in Cicer arietinum". Pakistan Journal of Botany vol. 24, pp. 4048, 1992.

[52] J. Jalilian, R. Khalilzadeh and E. Khanpaye, "Improving of barley seedling growth by seed priming under water deficit stress". J stress physiol and Biochem vol. 10, no. 2, pp. 125134, 2014.

[53] H. R. Rouhi, F. Sharif-Zadeh and M. A. Aboutalebian, "Alleviation of drought stress by seed priming in tall wheatgrass (Agropyron elongatum (Host) Beauv.). Int. J. of Plant Sci and Ecology vol. 1, no. 2, pp. 44-48, 2015.

[54] A. Espanany, S. Fallah, and A. Tadayyon, "Seed priming improves seed germination and reduces oxidative stress in black cumin (Nigella sativa) in presence of cadmium". Industrial Crops and Products vol. 79, pp. 195-204, 2016. http://doi.org/10.1016/j.indcrop.2015.11.016.

[55] B. K. Ghajari, M. Abbas, P. Rahmatollah, "Effects of silicon nanocolloid pre-treatment on seed germination characteristics of wheat (Triticum aestivum) under drought stress". Advances in Environmental Biology, vol. 9, no. 2, pp. 655-657, 2015.

[56] M. Aghbolaghi and M. Sedghi "The effect of osmo and hormone priming on germination and seed reserve utilization of millet seeds under drought stress". Journal of Stress Physiology \& Biochemistry vol. 10, no.1, pp. 214-221, 2014.

[57] A. M. Hamada and E. M. Khulaef, "Stimulative effects of ascorbic acid, thiamin or pyridoxine on Vicia faba growth and some related metabolic activities". Pak. J. Biological Sci vol. 3, no. 8, pp. 1330-1332, 2000.

[58] S. A. Sayed and M. A. A. Gadallah, "Effects of shoot and root application of thiamine on salt-stressed sunflower plants". Plant Growth Regulation vol. 36, no. 1, pp. 71-80, 2002.

[59] M. Arif, S. Ali, A. Shah, N. Javed and A. Rashid. "Seed priming maize for improving emergence and seedling growth". Sarhad Journal of Agriculture, vol. 21, pp. 17-20, 2005.

[60] I. Demir and H. A. Van De Venter, "The effect of priming treatments on the performance of watermelon (Citrullus lanatus (Thunb.) Matsum and Nakai) seeds under temperature and osmotic stress". Seed Sci Technol vol. 27, pp. 871-875, 1999.

[61] W. G. Hopkins, "Introduction to plant physiology". Wiley, New York, 1995.

[62] P. Moradi Dezfuli, F. Sharif-Zadeh and M. Janmohammadi, "Influence of priming techniques on seed germination behavior of maize inbred lines (Zea mays L.)". ARPN J. Agricultural and Biological Sciences vol. 3, no. 3, pp 22-25, 2008.

[63] W. Wang, B. Vinocur and A. Altman, "Plant responses to drought, salinity and extreme temperatures: Towards genetic engineering for stress tolerance". Planta vol. 218, pp. 1-14, 2003

[64] E. H. Roberts and R. D. Smith, "Dormancy and the pentose phosphate pathway", in A. A. Khan (Ed.) The Physiology and Biochemistry of Seed Dormancy and Germination. Elsevier
Biomedical Press. Amsberdam. pp. 385-411, 1977.

[65] J. R. Hilton and J. A. Thomas, "Regulation of pregerminative rates of respiration in seeds of various species by potassium nitrate". J Exp Botany vol. 37, pp. 1516-1524, 1986.

[66] H. W. M. Hilhorst and C. M. Karssen, Duel effect of light on the gibberellin and nitrate stimulated seed germination of Sisymbrium officinale and Arabidopsis thaliana. Plant Physiol vol. 86, pp. 591-597, 1988.

[67] A. A. Khan, N. H. Peck and C. Samimy, Seed osmoconditioning, physiological and biochemical changes. Israel J Bot vol. 29, pp. 133-144, 1981.

[68] A. Ahmadi, A. Sio-Se Mardeh, K. Poustini, and M. Esmailpour Jahromi. "Influence of osmo and hydropriming on seed germination and seedling growth in wheat (Triticum aestivum L.) cultivars under different moisture and temperature conditions". Pak J Biol Sci vol. 10, no. 22, pp. 4043-4049, 2007.

[69] F. Shafiq, H. Batool, S. H. Raza and M Hameed, "Effect of potassium nitrate seed priming on allometry of droughtstressed cotton (Gossypium hirsutum L.)". Journal of Crop Science and Biotechnology, vol. 18, no. 3, pp. 195-204, 2015 doi: 10.1007/s12892-015-0035-7.

[70] C. A. Jaleel, B. Sankar, R. Sridharan and R. Panneerselvam, "Soil salinity alters growth, chlorophyll content and secondary metabolite accumulation in Catharanthus roseus. Turk. J. Biol. Vol. 32, no. 2, pp. 79-83, 2008.

[71] M. Nabil, and A. Coudret, "Effect of sodium chloride on growth, tissue elasticity and solute adjustment in two Acacia nilotica subspecies", Plant Physiology vol. 93, pp. 217-224, 1995.

[72] A. Blum, "Drought resistance, water use efficiency and yield potential are they compatible, dissonant or mutually exclusive?" Aust. J Agric Res vol. 56, pp. 1159-1168, 2005.

[73] K. S. GolizadehS, M. M. Tooraj and K. Nabi, "Effect of Priming of $\left(\mathrm{KNO}_{3}, \mathrm{ZnSo}_{4}\right.$, Distilled water $)$ on rate Germination and Seedling Establishment on Cannabis seed (Cannabis sativa L.)" Biological Forum - An International Journal vol. 7, no. 1, pp. 190-194, 2015.

[74] Kalpana, A. H. Khan, A. K. Singh, K. N. Maurya, Mubeen, R. K. Yadava, U. Singh and A. R. Gautam, "Effect of different seed priming treatments on germination, growth, biochemical changes and yield of wheat varieties under sodic soil". Int. J, of Sci and Res. Vol. 4, no. 7, pp. 306-310, 2013.

[75] F. J. M. Maathuis and D. Sanders, "Mechanisms of potassium absorption by higher plant roots". Physiol Plant vol. 96, pp. 158-168, 1996.

[76] R. A. Mohammad and H. Mahmood, "Effect of potassium supply on drought resistance in sorghum: plant growth and macronutrition content". Pak J Agric Sci vol. 48, pp. 197-204, 2011.

[77] H. Gong, X. Zhu, K. Chen, S. Wang and C. Zhang, "Silicon alleviates oxidative damage of wheat plants in pots under drought". J. of Plant Science vol. 169, pp. 313-321, 2005.

[78] Y. H. Kim, A. L. Khan, M. Aqas, H.-J. Jeong, D. H. Kim, J. H Shin, J. G. Kim, M. H. Yeon, I. J. Lee, "Regulation of jasmonic acid biosynthesis by silicon application during physical injury to Oryza sativa L.". J Plant Res (2014) 127: 525-532, 2014a. DOI 10.1007/s10265-014-0641-3. 
[79] Y. H. Kim, A. L. Khan, D. H. Kim, S. Y. Lee, K. M. Kim, M. Waqas, H. Y. Jung, J. H. Shin, J. G. Kim and I. J. Lee, "Silicon mitigates heavy metal stress by regulating P-type heavy metal ATPases, Oryza sativa low silicon genes, and endogenous phytohormones". BMC Plant Biol vol. 14, pp. 13, 2014b. DOI: $10.1186 / 1471-2229-14-13$.

[80] A. M. EI-Zawahry and A. M. Hamada. "The effect of soaking seeds in ascorbic acid, pyridoxine or thiamine solutions on nematode, Meloidogyne javanica infection and on some metabolic processes in egg plant". Assiut J. Agric. Sci., vol. 25, pp. 233-248, 1994.

[81] D. A. Bender. "Amino Acid Metabolism". John Wiley and Sons Inc., New York, 1985.

[82] L. Yari, M. Aghaalikani and F. Khazaei, "Effect of seed priming duration and temperature on seed germination behaviour of bread wheat (Triticum aestivum L.). ARPN J Agric Biol Sci. vol. 5, no. 1, 2010. 